\title{
Penerapan Metode Cooperative Learning untuk Meningkatkan Hasil Belajar Renang Gaya Bebas
}

\author{
Sulikan \\ Program Studi Pendidikan Jasmani Kesehatan dan Rekreasi \\ IKIP Budi Utomo Malang \\ Jalan Simpang Arjuno 14 B Malang \\ Sulikan_ms@yahoo.co.id
}

\begin{abstract}
Education is a conscious and planned effort to create an atmosphere of learning and learning process so that learners actively develop their potential to have spiritual, religious, self-control, personality, intelligence, noble character and skills needed by him, nation and state society (UU Sistem National Education article 1 paragraph 1). Education is organized as a process of lifelong learning of the students by giving exemplary, building the will and developing the creativity of learners in the learning process and developing the culture of reading, writing and arithmetic. The objective of the study was to improve the learning outcomes of Free Styles Swimming through the implementation of Cooperative Learning method. The problem in this research is "Whether the application of cooperative learning method can improve the learning result of Freestyle Swimming. The method of this research is class action research which involves repetitive reflection and consists of four stages: planning, action, observation and reflection. The subject of this research is Student Physical Education Health and Recreation IKIP Budi Utomo Malang force 2014 as many as 30 people. The result of the research shows that before the implementation of learning with cooperative learning method, the value of free class swimming lesson (Pre Cycle) is only equal to 16,67\% with less category and in cycle I is implemented by applying cooperative learning method of learning result of freestyle pools $=63.33 \%$ with sufficient category and in cycle II which emphasize improvement in cycle I can be known implementation of cooperative learning method on free style swimming course increased and succeeded because able to reach $=93,33,00 \%$. This is in accordance with the classical completeness criteria (KKM), which is $70 \%$. In conclusion, the implementation of cooperative learning method can improve learning result of freestyle swimming at Student of Physical Education Health and Recreation IKIP Budi Utomo Malang Force 2014.
\end{abstract}

Keywords: Cooperative Learning Method, Learning Outcomes, Freestyle Swimming.

Salah satu materi dalam pendidikan jasmani, olahraga dan kesehatan yaitu renang. Dalam mengajarkan teknik dasar renang kepada anak didik tidak mudah. Dengan diberinya anak didik materi ini, diharapkan terjadi perubahan positif baik pengetahuan, keterampilan, dan sikap. Berkaitan dengan perubahan tersebut, belajar adalah merupakan suatu proses aktif yang perlu dirangsang dan dibimbing ke arah hasil-hasil yang diinginkan. Berbagai rangsangan dari luar yang menimbulkan peserta didik melakukan aktivitas belajar antara lain pengaruh dosen melaluipemberiantugas, pertanyaan-pertanyaan yang diajukan kepada peserta didik, bantuan visual yang digunakan dan semua proses yang lain yang digunakan untuk membangkitkan minat dan keinginan belajarnya.
Banyak faktor yang mempengaruhi rendahnya hasil belajar teknik dasar renang Gaya Bebas diantarannya keadaan mahasiswa yang heterogen, baik kemampuannya maupun karakteristik lainnya. Hal ini menyebabkan dosen dituntut kreatif dalam mengupayakan pembelajaran. Dosen harus pandai memilih metode pembelajaran, karena salah satu faktor penting yang turut mempengaruhi hasil belajar mahasiswa yaitu metode pembelajaran(Whyuni, 2010 ).

Berdasarkan fakta, diperlukan suatu alternatif metode pembelajaran yang dapat meningkatkan pencapaian hasil belajar menjadi lebih baik daripada hanya sekedar ceramah. Jika penyampaianmateriselalumenggunakanmetode ceramah, komunikasi yang berjalan searah yaitu 
dari faktor dosen saja. Salah satu metode yang dipilih dalam penelitian ini adalah cooperative learning. Cooperative learning merupakan metode pembelajaran yang mana mahasiswa belajar dan bekerja dalam kelompok-kelompok kecil secara kolaboratif yang anggotanya terdiri dari 5 sampai 6 orang, dengan struktur kelompok yang heterogen. (Saifullah Hijrah, 2012 )

Asumsi tersebut didasarkan atas beberapa hasil penelitian yang pernah dilakukan oleh Webb tahun 1985 yang menemukan bahwa dalam pembelajaran dengan menggunakan metode cooperative learning, sikap dan perilaku mahasiswa berkembang ke arah suasana demokratisasi. Di samping itu, penggunaan kelompok kecil dapat mendorong mahasiswa lebih bergairah dan termotivasi dalam mempelajarai materi pelajaran. Berdasarkan penelitian yang dilakukan Snaider, penggunaan metode cooperative learning sangat mendorong peningkatan prestasi belajar mahasiswa dengan perbedaan hampir 35\% dengan kemajuan dicapai oleh mahasiswa yang diajar menggunakan sistem kompetisi.

Berdasarkan temuan-temuan tersebut, penggunaan metode cooperativelearning memiliki efektivitas yang cukup tinggi bagi perolehan hasil belajar mahasiswa, baik dilihat dari pengaruhnya terhadap penguasaan materi pelajaran maupun dari pengembangan dan pelatihan sikap serta keterampilan sosial yang sangat bermanfaat bagi mahasiswa dalam kehidupannya di masyarakat. Hal ini diharapkan berlaku pula pada bidang studi pendidikan jasmani pada teknik dasar renang khususnya renang Gaya Bebas (Wahyuni, 2010).

Olahraga renang sangatlah beda dengan olahraga lain dan bergerak di air berbeda dengan brgerak di darat. Gerak manusia di darat pada umumnya pada posisi tegak atau vertikal dipengaruhi oleh gaya gravitasi bumi seutuhnya, sedangkan perenang yang bergerak di air dalam posisi horizontal di bawah pengaruh daya tarik bumi dikurangi oleh daya tekan air ke atas. Dalam keadaan normal, kita dapat bergerak bebas di bawah daya tarik bumi, sedangkan di dalam air kita harus belajar menyesuaikan gerakan denagn air. Hal tersebut akan terjadinya gerakan-gerakan yang nampaknya aneh. Lamakelamaan terciptalah gerakan-gerakan tertentu yang di anggap paling menguntungkan bagi seseorang pada waktu berenang, baik di tinjau dari segi mudahnya gerakan tersebut di lakukaan maupun di tinjau dari segi cepatnya melaju ke depan. (Muhajir, 2014:123)
Dari permasalahan yang dikemukakan di atas maka rumusan masalahnya adalah " Apakah Penerapan Metode Cooperative Learning dapat Meningkatkan Hasil Belajar Renang Gaya Bebas ?". Dan tujuan dari penelitian adalah " Untuk meningkatkan hasil belajar renang gaya bebas dengan penerapan metode cooperative learning.

\section{METODE}

Dalam suatu penelitian perlu menetapkan suatu metode yang sesuai dan dapat membantu mengungkapkan suatu permasalahan yang akan diteliti. Keberhasilan dalam penelitian ilmiah tidak akan lepas dari metode yang digunakan dalam penelitian tersebut. Penggunaan metode dalam penelitian disesuaikan dengan masalah dan tujuan penelitian. Metode penelitian mempunyai peran penting dalam melacak data dan menganalisisnya. Penelitian ini merupakan penelitian tindakan (action research). Karena penelitian ini dilakukan untuk memecahkan masalah pembelajaran dikelas. Penelitian ini juga termasuk penelitian deskriptif, sebab menggambarkan bagaimana suatu teknik pembelajaran diterapkan, dan bagaimana hasil yang diinginkan dapat dicapai. (Budi Susetyo. 2005)

Dalam penelitian tindakan ini menggunakan bentuk penelitian kolaboratif dengan dosen pembina matakuliah Praktek Renang dan didalam proses belajar mengajar dikelas yang bertindak sebagai pengajar adalah dosen pembina matakuliah Renang, sedangkan peneliti bertindak sebagai pengamat, penanggung jawab penuh penelitian tindakan adalah pengamat (peneliti). Tujuan utama dari penelitian tindakan ini adalah meningkatkan hasil pembelajaran dikelas dimana peneliti secara penuh terlibat dalam penelitian, mulai dari perencanaan, tindakan, pengamatan, dan refleksi.

Dalam penelitian ini peneliti bekerja sama dengan dosen pembina matakuliah Renang. Kehadiran peneliti ditengah-tengah proses belajar mengajar,sebagai pengamat diberitahukan kepada mahasiswa. Dengan cara ini diharapkan adanya kerjasama dari seluruh mahasiswa dan bisa mendapatkan data yang subjektif, demi kevalidan data yang diperlukan.

\section{Rancangan Penelitian}

Jenis penelitian yang digunakan adalah penelitian tindakan kelas (PTK). Penggunaan 
penelitian tindakan kelas dengan tujuan (1) memperbaiki dan meningkatkan mutu praktik pembelajaran yang dilaksanakan dosen demi tercapainya tujuan pembelajaran, (2) Mengidentifikasi, menemukan solusi, dan mengatasi masalah pembelajaran di kelas agar pembelajaran bermutu, (3) meningkatkan kemampuan dosen dalam memecahkan masalah-masalah pembelajaran, (4) menguji coba gagasan, pemikiran, kiat, cara, dan strategi baru dalam pembelajaran untuk meningkatkan mutu pembelajaran selain kemampuan inovatif dosen, dan (5) mengekplorasi pembelajaran yang selalu berwawasan atau berbasis penelitian agar pembelajaran dapat bertumpu pada realitas empiris kelas, bukan semata-mata bertumpu pada kesan umum atau asumsi. Rancangan penelitian tindakan kelas dipilih karena (1) penelitian pembelajaran yang berkonteks kelas dilaksanakan oleh dosen untuk memecahkan masalah-masalah pembelajaran untuk meningkatkanhasil belajar renang Gaya Bebas, memperbaiki mutu pembelajaran, dan mencoba hal-hal yang baru untuk peningkatan hasil belajar renang Gaya Bebas, (2) penelitian dilakukan untuk mengubah keadaan, kenyataan, dan harapan mengenai pembelajaran ketrampilan teknik dasar menjadi lebih baik dan bermutu dengan cara melakukan sejumlah tindakan yang dipandang tepat, (3) bentuk kajian yang dilakukan di kelas yang bersifat reflektif oleh dosen untuk meningkatkan kemampuan rasional dalam melaksanakan tugas, memperdalam pemahaman terhadap tindakan-tindakan yang dilakukannya, dan memperbaiki praktik-praktik pembelajaran, maka penelitian dilakukan pada konteks alamiah, ialah untuk mengkaji permasalahan faktual dalam pembelajaran, dan (4) dalam pelaksanaannya penelitian ini membutuhkan keterlibatan dosen pembina matakuliah Renang dan mahasiswa serta peneliti secara kolaboratif selama penelitian berlangsung. Sehubungan dengan itu, dapat dikemukakan bahwa karakteristik penelitian tindakan kelas adalah (1) bersifat siklus, karena dilaksanakan terikat oleh siklus-siklus mulai dari perencanaan, pemberian tindakan, pengamatan, dan refleksi sebagai prosedur penelitiannya, (2) bersifat longitudinal, penelitiannya berlangsung dalam jangka waktu tertentu secara kontinyu untuk memperoleh data yang diperlukan, (3) bersifat partikularspesifik yang tidak bermaksud melakukan generalisasi dalam rangka memperoleh dalil- dalil, (4) bersifat emik, penelitian tindakan kelas memandang pembelajaran menurut sudut pandang orang dalam yang tidak berjarak dengan peneliti, (5) bersifat kolaborasi, dalam pelaksanaan penelitian tindakan kelas terjadi kerjasama antara peneliti dengan pihak lain demi keabsahan dan tercapainya tujuan penelitian, (6) bersifat kasuistik, artinya penelitian tindakan kelas menggarap kasuskasus spesifik atau tertentu dalam pembelajaran yang bersifat nyata dan terjangkau oleh dosen, (7) menggunakan konteks alamiah kelas, kelas sebagai ajang pelaksanaan penelitian tindakan kelas tidak perlu dimanipulasi dan atau direkayasa demi kebutuhan, kepentingan, dan tercapainya tujuan penelitian, (8) menggunakan adanya kecukupan data yang diperlukan untuk mencapai tujuan penelitian, dan (9) mempunyai maksud mengubah kenyataan, keadaan, dan situasi pembelajaran menjadi lebih baik dan memenuhi harapan.( Budi Susetyo. 2005 ) Berdasarkan karakteristik tersebut, penelitian ini dilakukan untuk Meningkatkan hasil belajar renang Gaya Bebas melalui penerapan metode cooperative learning pada Mahasiswa Pendidikan Jasmani Kesehatan Dan Rekreasi IKIP Budi Utomo Malang Angkatan 2014.

Penerapan metode cooperative learning tindakan tersebut bertujuan untuk mengatasi masalah pembelajaran. Meningkatkan hasil belajar teknik dasar renang Gaya Bebas karena: (1) mahasiswa menemui kesulitan disaat melakukan teknik dasar renang Gaya Bebas, baik individu maupun kelompok. (2) mahasiswa menemui kesulitan dalam mengembangkan latihan renang Gaya Bebas, baik individu maupun maupun secara kelompok.

Proses pelaksanaan penelitian tindakan kelas ini merujuk pada pendapat Suharismi Arikunto, dkk. ( 2008 ) dalam P3G ( 2013 ) yang menjelaskan tahap-tahap penelitian tindakan yang dimulai dari (1) menyusu $n$ perencanaan (plan), (2) melaksanakan tindakan (act), (3) pengamatan (observe), dan (4) refleksi (reflect). Dengan demikian penelitian tindakan merupakan suatu proses yang memiliki siklus yang bersifat spiral, mulai dari perencanaan, melakukan tindakan, dan penemuan fakta-fakta melalui refleksi.

Dalam pelaksanaan penelitian tindakan kelas untuk lebih jelasnya digambarkan alur penelitian tindakan kelas. Alur penelitian tindakan ini dapat digambarkan dalam bentuk bagan sebagaimana pada halaman berikutnya. 


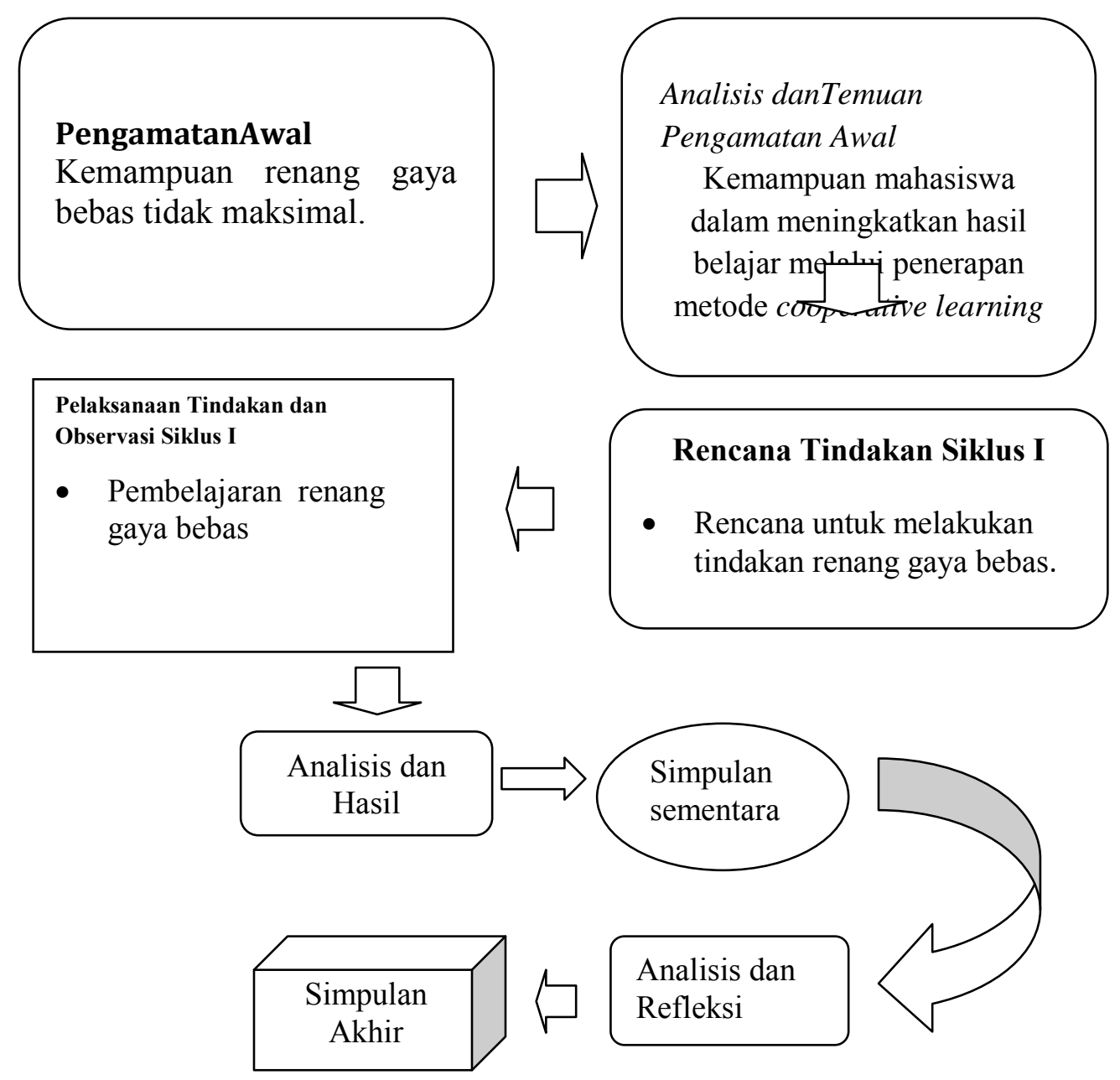

Gambar 3.1 Alur Penelitian Tindakan Kelas Diadaptasikan dari Arikunto, dkk (2008)

PTK terdiri atas 4 tahap, yaitu pleaning (rencana), action (tindakan), observasi (pengamatan) dan reflection (refleksi). Siklus spiral dari tahap-tahap PTK dapat dilihat pada rancangan/gambaran berikut :

1. Rancangan/rencana awal, sebalum mengadakan penelitian, peneliti menyusun rumusan masalah, tujuan dan membuat rencana tindakan, termasuk didalamnya instrument penelitian dan perangkat pembelajaran.

2. Kegiatan dan pengamatan meliputi tindakan yang dilakukan peneliti sebagai upaya membangun pemahaman konsep mahasiswa serta mengamati hasil atau dampak dari ditetapkannya metode kelincahan dan kecepatan.

3. Refleksi, peneliti mengkaji, melihat, dan mempertimbangkan hasil atau dampak dari tindakan yang dilakukan berdasarkan lembar pengamatan yang diisi oleh pengamat.
4. Rancangan/rencanayangrevisi,berdasarkan hasil refleksi dari pengamat membuat rancangann yang direfisi utuk dilaksanakan pada siklus berikutnya.

Observasi terbagi kedalam dua putaran, dimana pada masing-masing putaran dikenal perilaku yang sama (alur kegiatan yang sama) dan membahas satu sub pokok bahasan yang diakhiri masing-masing putaran. Dibuat dalam dua putaran dimaksudkan untuk memperbaiki sistem pembelajaran yang dilaksanakan.

\section{Tempat, Waktu dan Subjek Penelitian}

Tempat penelitian adalah tempat yang digunakan dalam melakukan penelitian untuk memperoleh data yang diinginkan. Penelitian ini bertempat di Kampus IKIP Budi Utomo Malang. Waktu penelitian adalah waktu berlangsungnya penelitian atau saat penelitian ini dilangsungkan. Penelitian ini dilaksanakan pada bulan 11 
Mei s/d 8 Juni 2015. Subyek penelitian adalah Mahasiswa Pendidikan Jasmani Kesehatan Dan Rekreasi IKIP Budi Utomo Malang Angkatan 2014 dengan jumlah 30 mahasiswa.

\section{Instrumen Penelitian}

Instrumen kunci atau utama dalam penelitian ini adalah peneliti. Dalam hal ini peneliti secara berkesinambungan mengamati, mencatat, merefleksi, dan mempelajari secara mendalam seluruh rangkaian pembelajaran. Rangkain pembelajaran ini meliputi perencanaan, pelaksanaan, dan pengevaluasian pembelajaran.

Instrumen pendukung penelitian yang digunakan adalah lembar pedoman observasi, lembar catatan lapangan, lembar refleksi, dan lembar penugasan. Observasi digunakan untuk mengamati kegiatan mahasiswa pada saat kegiatan pembelajaran berlangsung.Pengamatan ini dilakukan terhadap aktivitas mahasiswa dalam pembelajaran keterampilan teknik dasar renang Gaya Bebas. Kegiatan observasi diarahkan untuk memperoleh data tentang kegiatan yang dilakukan mahasiswa pada setiap tahapan keterampilan dasar renang Gaya Bebas melalui penerapan metode cooperative learning.

Pada tahap pengidentifikasian, observasi dilakukan berdasarkan langkah-langkah tindakan pembelajaran pada tahap tersebut. Urutan langkah observasi tersebut adalah, (1) pengamatan terhadap aktivitas mahasiswa dalam melakukan renang Gaya Bebas melalui penerapan metode cooperative learning (2) pengamatan terhadap aktivitas mahasiswa dalam melakukan latihan renang Gaya Bebas.

(3) Pengevalusian.

Pada tahap pendalaman observasi dilakukan dengan langkah-langkah sebagai berikut (1) pengamatan terhadap aktivitas mahasiswa dalam kegiatan melakukan kemampuan renang Gaya Bebas melalui penerapan metode cooperative learning dan pengembangannya berdasarkan pengetahuan dan pengalaman mahasiswa lainnya, (2) pengamatan terhadap aktivitas mahasiswa dalam kegiatan meningkatkan hasil belajarrenang Gaya Bebas, aktivitas/ tindakan dan pengembangannya berdasarkan pengetahuan dan pengalaman mahasiswa lainnya, (3) pengamatan terhadap aktivitas mahasiswa dalam kegiatan latihan renang Gaya Bebas, beberapa fungsi dan pengembangannya berdasarkan pengetahuan dan pengalaman mahasiswa lainnya.
Tahap pelaporan observasi dilakukan dengan langkah-langkah sebagai berikut (1) pengamatan terhadap aktivitas mahasiswa dalam kegiatan melaporkan permasalahan kemampuan renang Gaya Bebas khusus secara individual, (2) pengamatan terhadap aktivitas mahasiswa dalam kegiatan melaporkan unsur aktivitas/tindakan dan permasalahan latihan renang Gaya Bebas khusus secara individual, dan (3) pengamatan terhadap aktivitas mahasiswa dalam kegiatan melaporkan permasalahannya kemampuan secara individual.

Silabus digunakan sebagai acuan dalam pembelajaran yang berpedoman kepada kurikulum yang digunakan. Dalam hal ini, silabus mengacu pada kurikulum KTSP 2006 olahraga dan kesehatan.

Rencana Pembelajaran digunakan untuk acuan urutan pembelajaran yang dilaksanakan dalam proses belajar-mengajar teori dan praktek di kolam renang lembah dieng malang. Urutan kegiatannya meliputi pendahuluan, kegiatan inti, dan refleksi. Lembar pengamatan awal digunakan untuk mengetahui dan memperoleh temuan kegiatan pembelajaran terutama pembelajaran kemampuan renang Gaya Bebas melalui penerapan metode cooperative learningyang sudah dilakukan berlangsung secara efektif dan menarik atau belum. Lembar observasi digunakan untuk mencatat aktivitas yang dilakukan mahasiswa selama pembelajaran berlangsung. Lembar refleksi bertujuan untuk mencatat kekurangan-kekurangan dalam proses belajar mengajar berlangsung, yang nantinya digunakan untuk menganalisis kegiatan yang telah dilakukan. Lembar evaluasi digunakan untuk pedoman penilaian dalam pembelajaran renang yaitu kemampuan meningkatkan hasil belajarr enang Gaya Bebas melalui penerapan metode cooperative learning.

\section{Prosedur Penelitian}

Prosedur penelitian tindakan ini dibedakan antara persiapan penelitian dan pelaksanaan penelitian. Uraian kedua hal itu dapat diuraikan sebagai berikut:

\section{Persiapan Penelitian}

Kegiatan penelitiandimulaidaripengamatan awal terhadap latar penelitian yang meliputi, mahasiswa, dan kegiatan belajar mengajar kemampuan renang Gaya Bebas. Selanjutnya diadakan analisis hasil pengamatan awal dan diperoleh temuan bahwa pembelajaran keterampilan teknik dasar renang Gaya Bebas 
Mahasiswa Pendidikan Jasmani Kesehatan Dan Rekreasi IKIP Budi Utomo Malang Angkatan 2014 belum dilaksanakan secara optimal dan kurang menarik pelaksanaannya bagi mahasiswa. Berdasarkan temuan tersebut mahasiswa masih mengalami kesulitan dalam memaksimalkan teknik renang Gaya Bebas. Kemudian disusun suatu rencana tindakan untuk diterapkan metode cooperative learning dalam pembelajaran teknik dasar renang Gaya Bebas. Rencana tindakan tersebut dituangkan dalam persiapan mengajar yang akan digunakan dalam siklus tindakan.

Sebelum mengamati kegiatan pembelajaran di kolam dan dikelas diadakan pertemuan dengan dosen renang Pendidikan Jasmani Kesehatan Dan Rekreasi IKIP Budi Utomo Malang, untuk meminta persetujuan, untuk mengadakan penelitian tindakan kelas pada mahasiswa tersebut. Rencana tersebut di setujui oleh dosen renang. Selanjutnya, kegiatan yang dilakukan adalah mengamati secara langsung proses pembelajaran dan praktek di lapangan . Selain itu, juga dilakukan pengamatan terhadap kegiatan mahasiswa dalam proses belajar. Kegiatan wawancara terhadap dosen dan mahasiswa dilakukan pula agar didapatkan hasil pengamatan yang dapat dipertanggungjawabkan.

Hasil observasi dan wawancara pada kegiatan pengamatan awal tersebut menunjukkan bahwa pembelajaran teknik dasar renang Gaya Bebas belum dilaksanakan secara optimal. Pembelajaran masih dititik beratkan pada cara pembelajaran lama. Mahasiswa nampak masih menemukan kendala dalam pembelajaran itu. Dari hasil wawancara dengan mahasiswa, pembelajaran teknik dasar renang Gaya Bebas yang pernah dilakukan yang telah dialami mahasiswa dalam pembelajaran renang Gaya Bebas tersebut diperoleh temuan bahwa mahasiswa masih menemui beberapa kendala dalam pembelajaran teknik dasar renang Gaya Bebas, kendala-kendala yang dapat di identifikasi, yaitu; (1) Mahasiswa menemui kesulitan di dalam mengidentifikasikan teknik dasar renang Gaya Bebas melalui individu maupun kelompok. (2) mahasiswa menemui kesulitandalam mengembangkan pemebelajaran renang Gaya Bebas, baik individu maupun kelompok. Berdasarkan temuan tersebut maka disusun suatu rencana tindakan kelas untuk menerapkan metode cooperative learning dalam pembelajaran teknik dasar renang Gaya Bebas.

\section{Pelaksanaan Penelitian}

Pada bagian ini dikemukakan tentang tahap perencanaan, tahap pelaksanaan, tahap observasi, dan tahap refleksi.

\section{a. Tahap Perencanaan}

Setelah mengadakan pengamatan awal, disusun rencana tindakan berupa penerapan metode cooperative learning untuk meningkakan hasil belajar renang Gaya Bebas. Rencana tindakan ini dengan melakukan kegiatan, (1) merancang kegiatan pembelajaran, (2) menyusun dan mempersiapkan instrumen penelitian, (3) menetapkan dan menyusun jadwal pelaksanaan tindakan peningkatan hasil belajar renang Gaya Bebas melalui penerapan metode cooperative learning.

Kegiatan pertama adalah merancang kegiatan pembelajaran. Rancangan kegiatan pembelajaran meliputi, (1) pembuatan silabus, (2) pembuatan rencana pembelajaran. Dalam pembuatan silabus dan rencana pembelajaran sebagaikurikulumacuanadalahkurikulumtahun 2006 KTSP.Silabus dan rencana pembelajaran yang dirancang untuk dilaksanakan dalam satu siklus yang terdiri dari satu silabus pembelajaran dan lima rencana pembelajaran. Setiap rencana pembelajaran dirancang untuk dilaksanakan pada satu kali pertemuan dengan alokasi waktu 2 × 45 menit. Karena penelitian ini rencananya dilaksanakan dua siklus, maka silabus dan rencana pembelajaran juga dirancang untuk dilaksanakan dalam dua siklus dengan memperhatikan hasil refleksi yang dilakukan setiap akhir tindakan satu siklus. Untuk silabus dan rencana pembelajaran untuk siklus dua pada dasarnya sama dengan siklus pertama, hanya ada tahap perevisian. Revisi dapat dilakukan oleh mahasiswa sendiri atau silang dengan teman.( Departemen Pendidikan Nasional, 2006 )

Kegiatan kedua adalah menyusun dan mempersiapkan instrumen penelitian. Setelah merancang kegiatan pembelajaran, kemudian menyusun dan mempersiapkan instrumen penelitian. Adapun kegiatannya adalah, (1) membuat format catatan lapangan, (2) membuat pedoman wawancara dosen renang dan mahasiswa, (3) membuat rambu-rambu analisis proses, (4) membuat format pedoman penilaian tes renang Gaya Bebas melalui penerapan metode cooperative learning. .( Departemen Pendidikan Nasional, 2006 )

Kegiatan ketiga adalah menyusun jadwal pelaksanaan tindakan. Jadwal disusun 
berdasarkan jadwal kegiatan ekstrakurikuler. Pertemuan pada siklus pertama dilaksanakan fokus pada pembelajaran melalui pembelajaran renang Gaya Bebas dengan penerapan metode cooperativelearning padatahappengidentifikasian. Pelaksanaan pada siklus selanjutnya disusun setelah melihat hasil refleksi tindakan pada siklus pertama.

\section{b. Tahap Pelaksanaan}

Tahap ini merupakan realisasi dari tahap perencanaan tindakan. Pada tahap ini dosen melaksanakan pembelajaran di Kolam Renang Lembah Dieng Malang berdasarkan perencanaan tindakan pembelajaran dalam setiap siklus. Setiap siklus memerlukan waktu 2 jam pelajaran ( $2 \times 45$ menit) yang dilaksanakan 1 kali pertemuan dalam 1 minggu. Dalam pelaksanaannya, setiap siklus tindakan yang dilakukan dalam pembelajaran teknik renang Gaya Bebas dengan penerapan metode cooperative learning pada tahap pengidentifikasian, pendalaman, dan pelaporan. Pelaksanan pembelajaran disajikan sebagai berikut:

Pertemuan pertama kegiatannya adalah fokus pada tahap pengidentifikasian. Pada tahap pengidentifikasian kegiatan yang dilakukan mahasiswa adalah sebagai berikut: pada siklus yang pertama untuk pembelajaran renang Gaya Bebas melalui penerapan metode cooperative learning.

\section{c. Tahap Observasi}

Kegiatan observasi dilakukan dengan pelaksanaan tindakan pembelajaran. Dalam kegiatan ini, semua indikator berusaha dikenali dan didokumentasikan dengan menggunakan pedoman observasi.

Observasi dilakukan setiap tindakan pada setiap siklus. Observasi yang dilakukan siklus pertama dapat mempengaruhi penyusunan pada siklus selanjutnya. Hasil pengamatan ini, kemudian diadakan refleksi untuk perencanaan siklus berikutnya.

\section{d. Tahap Refleksi}

Refleksi diadakan setiap akhir siklus. Dalam tahap ini diadakan, (1) menganalisis tindakan yang baru dilakukan, (2) membahas kesesuaian tindakan dengan perencanaan yang telah dilaksanakan, (3) menemukan pemecahan masalah apabila terdapat kendala dalam pelaksanaan kegiatan, dan (4) melakukan pemaknaan dan penyimpulan data yang diperoleh.

Hasil refleksi merupakan masukan untuk menentukan perlu tidaknya tindakan pada siklus berikutnya. Tindakan pada siklus berikutnya tidak perlu dilaksanakan apabila hasil pada refleksi menunjukan keberhasilan yang signifikan.

\section{Teknik Pengumpulan Data}

Didalam kegiatan penelitian, cara memperoleh data ini dikenal sebagai metode pengumpulan data. Metode pengumpulan data yang lazim dilakukan dalam penelitian tindakan kelas adalah metode observasi, wawancara, kuisioner, dokumentasi dan tes, yang kesemuanya merupakan sebagian dari metode pengumpulan data. Cara pengumpulan data yang digunakan di dalam penelitian ini adalah dengan diadakannya tes sedangkan pengertian tes itu sendiri adalah serentetan pertanyaan atau latihan atau metode pembelajaran lain yang digunakan untuk mengukur keterampilan, pengetahuan,intelegensi,kemampuanataubakat yang dimiliki oleh individu atau kelompok.

\section{Teknik Analisis Data}

Untuk menentukan teknik analisis data, peneliti menggunakan analisis deskriptif. Untuk menentukan ketuntasan individual, peneliti menggunakan rumus oleh M. Yunus, 2009, sebagai berikut:

$$
\mathrm{NA}=\frac{\mathrm{SHT}}{\mathrm{SMI}} \times \mathrm{NI}
$$

\section{Keterangan:}

NA : Nilai Akhir

SHT : Skor Hasil Tes

SMI : Skor Maksimum Ideal (16)

NI : Nilai Ideal (dalam skala 100\%)

Untuk menentukan ketuntasan secara klasikal, menggunakan rumus dari Rochiati Wiriatmadja. 2007, sebagai berikut:

$$
\mathrm{KB}=\frac{\text { Jumlah Siswa Tuntas }}{\text { Jumlah Keseluruha } \mathrm{n} \text { Siswa }} \times 100 \%
$$

Keterangan:

KB : Ketuntasan Belajar

Data hasil belajar mahasiswa di analisis dengan menggunakan Kriteria Ketuntasan Minimal (KKM). Mahasiswa disebut tuntas belajar jika telah mencapai Kriteria Ketuntasan Minimal (KKM). KKM di Program Pendidikan Jasmani Kesehatan Dan Rekreasi Studi adalah 70\%. Hasil belajar mahasiswa dikatakan meningkat jika mahasiswa telah menunjukkan adanya peningkatan hasil pembelajaran dari 
siklus pertama ke siklus kedua baik presentase ketuntasan klasikal maupun rata-rata klasikal.

Perolehan data selama penelitian akan dianalisis sebagai berikut:

\section{Kriteria penilaian}

Setelah menentukan kriteria tingkat penguasaan matakuliah, kemudian peneliti menentukan kriteria tingkat penguasaan materi teknik renang Gaya Bebas, sebagai berikut :

Skor maksimal setiap kesempatan $=12(4 \times 3$ indikator )

Tabel 3. 1 skor penilaian renang Gaya Bebas

\begin{tabular}{|c|c|c|c|}
\hline No & Indikator penilaian & Skor & Keterangan \\
\hline \multirow[t]{4}{*}{1} & TES PSIKOMOTOR & 4 & Melakukan langkah-langkah renang Gaya Bebas 'sangat baik' \\
\hline & & 3 & Melakukan langkah-langkah renang Gaya Bebas dengan 'baik' \\
\hline & & 2 & Melakukan langkah-langkah renang Gaya Bebas 'cukup' \\
\hline & & 1 & Melakukan langkah-langkah renang Gaya Bebas 'kurang' \\
\hline \multirow[t]{5}{*}{2} & TES AFEKTIF & & $\begin{array}{l}\text { Unsur-unsur yang dinilai :menolong, memberi semangat, men- } \\
\text { taati, kesungguhan. }\end{array}$ \\
\hline & & 4 & Melaksanakan semua unsur yang diatas ‘sangat baik' \\
\hline & & 3 & Melaksanakan semua unsur yang diatas dengan 'baik' \\
\hline & & 2 & Melaksanakan semua unsur yang diatas 'cukup' \\
\hline & & 1 & Melaksanakan semua unsur yang diatas ' kurang'. \\
\hline \multirow[t]{4}{*}{3} & TES KOGNIKTIF & 4 & Mahasiswa dapat menjawab 3 pertanyaan. \\
\hline & & 3 & Mahasiswa dapat menjawab 2 pertanyaan. \\
\hline & & 2 & Mahasiswa dapat menjawab 1 pertanyaan. \\
\hline & & 1 & Tidak dapat menjawab semua pertanyaan \\
\hline
\end{tabular}

Sesuai table di atas, diketahui skor maksimal yang dapat diperoleh mahasiswa pada setiap kesempatan tes untuk tiap indikator adalah 4, sehingga total skor maksimal mahasiswa pada tiap kesempatan tes adalah 12 ( 4 X 3 indikator), dan skor minimalnya adalah 3 ( 1 X 3 indikator ). Skor akhir maksimal yang dapat diperoleh mahasiswa adalah 36 ( 4 X 3 indikator $X 3$ kesempatan tes ), dan skor minimal yang dapat diperoleh adalah 9 ( 1 X 3 indikator X 3 kesempatan tes).
Skor minimal setiap kesempatan $=3\left(\begin{array}{l}1 \\ \times\end{array}\right.$ indikator )

Skor maksimal hasil tes $=36(4 \times 3$ indikator $\mathrm{X} 3$ kesempatan tes )

Skor minimal hasil tes $=9(1 \times 3$ indikator $\times 3$ kesempatan tes )

Jumlah indikator penilaian $=3$ ( keterampilan (psikomotor), sikap (afektif), pengetahuan (kognitif).

Tabel 3. 2 Kriteria tingkat penguasaan Kompetensi Penjaskes

\begin{tabular}{ccc}
\hline Tingkat penguasaan & Nilai huruf & Predikat \\
\hline $88 \%-100 \%$ & $\mathrm{~A}$ & Sangat Baik \\
$70 \%-87 \%$ & $\mathrm{~B}$ & Baik \\
$62 \%-74 \%$ & $\mathrm{C}$ & Cukup \\
$<62 \%$ & $\mathrm{D}$ & Kurang \\
\hline
\end{tabular}

Tabel 3. 3 Kriteria tingkat penguasaan Teknik Renang Gaya Bebas

\begin{tabular}{ccc}
\hline Tingkat penguasaan ( skor akhir tes ) & Nilai huruf & Predikat \\
\hline $32-36$ & A & Sangat Baik \\
$27-31$ & B & Baik \\
$22-26$ & C & Cukup \\
$<22$ & D & Kurang \\
\hline
\end{tabular}




\section{HASIL PENELITIAN DAN PEMBAHASAN}

\section{Data Hasil Tes Awal (Pra Siklus)}

Berdasarkan data hasil tes awal (Pra Siklus) renang Gaya Bebas, untuk kemampuan penguasaan materi, dapat dikelompokan kategori hasil belajar pada tabel di bawah ini.

Tabel 4.2 Lembar refleksi tingkat ketuntasan Tes Awal (Pra Siklus) Hasil Belajar Renang individu sebelum penerapan metode cooperative learning.

\begin{tabular}{|c|c|c|c|c|c|c|}
\hline \multirow[t]{2}{*}{ No } & \multirow[t]{2}{*}{ Nama Mahasiswa } & \multicolumn{2}{|c|}{$\mathrm{NA}=\underline{\mathrm{SHT}} \times \mathrm{SMI}$} & \multirow[t]{2}{*}{ Predikat } & \multirow[t]{2}{*}{ ( T ) Tuntas } & \multirow[t]{2}{*}{ ( TT ) Tidak Tuntas } \\
\hline & & Skor & Nilai ( \%) & & & \\
\hline 1 & BAYU WIDIANTO & 20 & 55,55 & $\mathrm{D}$ & & $\sqrt{ }$ \\
\hline 2 & RIMUDI & 33 & 91,66 & $\mathbf{A}$ & $\sqrt{ }$ & \\
\hline 3 & FRIDATA YODHO & 24 & 66,66 & $\mathrm{C}$ & & $\sqrt{ }$ \\
\hline 4 & DANAG YOGI & 24 & 66,66 & $\mathrm{C}$ & & $\sqrt{ }$ \\
\hline 5 & SANDI ARIF H. & 28 & 77,77 & B & $\sqrt{ }$ & $\sqrt{ }$ \\
\hline 6 & ADITYA WAHYU P & 19 & 52,77 & D & & $\sqrt{ }$ \\
\hline 7 & INDRA BAGUS W. & 25 & 69,44 & $\mathrm{C}$ & & $\sqrt{ }$ \\
\hline 8 & DODO ERWIN D. & 21 & 58,33 & $\mathrm{D}$ & & $\sqrt{ }$ \\
\hline 9 & UBAIDILLAH & 22 & 61,11 & $\mathrm{C}$ & & $\sqrt{ }$ \\
\hline 10 & NELSON LANDU T & 24 & 66,66 & $\mathrm{C}$ & & $\sqrt{ }$ \\
\hline 11 & M. SUPRIYADI & 25 & 69,44 & $\mathrm{C}$ & & $\sqrt{ }$ \\
\hline 12 & FACHRI BA. & 32 & 88,88 & $\mathbf{A}$ & $\sqrt{ }$ & \\
\hline 13 & MOH. NUR S. & 23 & 63,88 & $\mathrm{C}$ & & $\sqrt{ }$ \\
\hline 14 & SATRIO WAHYU & 20 & 55,55 & D & & $\sqrt{ }$ \\
\hline 15 & SUBHAN W. & 26 & 72,22 & $\mathrm{C}$ & & $\sqrt{ }$ \\
\hline 16 & FAHMI Q & 30 & 83,33 & B & $\sqrt{ }$ & \\
\hline 17 & YOHANES A. & 21 & 58,33 & $\mathrm{D}$ & & $\sqrt{ }$ \\
\hline 18 & WILDAN FAHMI & 25 & 69,44 & $\mathrm{C}$ & & $\sqrt{ }$ \\
\hline 19 & ARIF RAHMAN K. & 33 & 91,66 & $\mathbf{A}$ & $\sqrt{ }$ & \\
\hline 20 & DELIANUS S. & 24 & 66,66 & $\mathrm{C}$ & & $\sqrt{ }$ \\
\hline 21 & MARTINUS PA. & 26 & 72,22 & $\mathrm{C}$ & & $\sqrt{ }$ \\
\hline 22 & HENDRA & 23 & 63,88 & $\mathrm{C}$ & & $\sqrt{ }$ \\
\hline 23 & JURIANDRA S. & 19 & 52,77 & D & & $\sqrt{ }$ \\
\hline 24 & SUSETIONO MA. & 25 & 69,44 & $\mathrm{C}$ & & $\sqrt{ }$ \\
\hline 25 & WAWAN A. & 21 & 58,33 & D & & $\sqrt{ }$ \\
\hline 26 & IQBAL W. & 21 & 58,33 & D & & $\sqrt{ }$ \\
\hline 27 & JONI ANGGARA & 26 & 72,22 & $\mathrm{C}$ & & $\sqrt{ }$ \\
\hline 28 & MOH. ABIDIN & 20 & 55,55 & D & & $\sqrt{ }$ \\
\hline 29 & RIZKI NURCAHYO & 24 & 66,66 & $\mathrm{C}$ & & $\sqrt{ }$ \\
\hline \multirow[t]{3}{*}{30} & ONGKY DANGE U & 23 & 63,33 & $\mathrm{C}$ & & $\sqrt{ }$ \\
\hline & Jumlah $=$ & 727 & 2018,73 & & 5 & 25 \\
\hline & Rata-rata $=$ & 24,23 & 67,29 & C(Cukup) & $=16,67 \%$ & $=63,33 \%$ \\
\hline
\end{tabular}


10 | Sulikan, Penerapan Metode Cooperative Learning ...

Tabel 4.1 Presentase (\%) Ketuntasan Hasil Belajar Renang Gaya Bebas Test Awal (Pra Siklus)

\begin{tabular}{llcccc}
\hline No. & Kategori & $\begin{array}{c}\text { Jumlah } \\
\text { mahasiswa }\end{array}$ & $\begin{array}{c}\text { Presentase } \\
\mathrm{KB}=\frac{\mathrm{F}}{\mathrm{N}} \times 100 \%\end{array}$ & $\begin{array}{c}\text { Akumulasi } \\
\text { Ketuntasan }\end{array}$ & T/TT \\
\hline 1. SANGAT BAIK & 3 & $10 \%$ & $10 \%$ & 5 Mahasiswa tuntas \\
2. & BAIK & 2 & $6,67 \%$ & $6,67 \%$ & 25 mahasiswa tidak tuntas \\
3. CUKUP & 16 & $53,33 \%$ & - & - \\
4. KURANG & 9 & $26,67 \%$ & $16,67 \%$ & \\
TOTAL & 30 & $100 \%$ &
\end{tabular}

\section{Keterangan :}

$\mathrm{KB}=$ Ketuntasan Belajar

$\mathrm{F}=$ Frekuensi mahasiswa tuntas / tidak tuntas

$\mathrm{N}=$ Jumlah seluruh mahasiswa

Sesuai dengan data tes awal (Pra Siklus), maka ketuntasan belajar mahasiswa secara klasikal untuk materi renang Gaya Bebas sebesar $16,67 \%$, dengan penghitungan, yaitu:

$$
\begin{aligned}
& \mathrm{KB} \quad \mathrm{X} 100 \% \\
& \mathrm{~KB}=(5: 30) \times 100 \%=16,67 \%
\end{aligned}
$$

Disimpulkan bahwa menurut data hasil tes awal (Pra Siklus) pada Mahasiswa Pendidikan Jasmani Kesehatan Dan Rekreasi IKIP Budi Utomo Malang, untuk penguasaan materi secara klasikal, yaitu kemampuan Renang Gaya Bebas "tergolong dalam kriteria D = Kurang", karena hanya 5 mahasiswa yang tuntas $=16.67 \%$ dan sebanyak 25 mahasiswa tidak tuntas $=63,33 \%$ tidak tuntas dari jumlah mahasiswa sebanyak 30 orang, sedangkan kriteria ketuntasan secara klasikal adalah $70 \%$. Oleh karena itu, peneliti selanjutnya menerapkan model pembelajaran Cooperative Learning pada siklus I.

\section{Penelitian Tindakan Kelas Siklus I}

\section{a. Perencanaan}

Perencanaan ini dilaksaankan dengan menentukan waktu tindakan, kelas yang digunakan untuk penelitian, pencatatan tindakan dan pembuatan RPP. Penentuan waktu tindakan ini berkaitan dengan pelaksanaan penelitian yang dilaksanakan pada hari Senin tanggal 11 Mei dan 18 Mei 2015, langkah selanjutnya menetukan kelas yang akan diberi tindakan adalah mahasiswa Pendidikan Jasmani Kesehatan Dan Rekreasi IKIP Budi Utomo Malang angkatan 2014, dipilihnya mahasiswa Pendidikan Jasmani Kesehatan Dan Rekreasi kerena kurangnya gairah dan minat dalam mengikuti pembelajaran renang khususnya renang Gaya Bebas.

\section{b. Pengamatan}

Hasil dari pengamatan selama proses pembelajaran berlangsung, mahasiswa dalam mengikuti pembelajaran renang Gaya Bebas cukup antusias, memahami setiap tahapan renang Gaya Bebas seperti yang dicontoh oleh peneliti.Secara umum suasana mahasiswa cukup aktif ini terlihat dari antusiasme mahasiswa dalam mengikuti pembelajaran, dari pemanasan sampai serangkaian gerakan renang Gaya Bebas. mahasiswa mengikuti apa yang diperintahkan oleh si peneliti

\section{c. Refleksi}

Tindakan selanjutnya adalah melakukan refleksi dari semua tindakan yang dilakukan, hasilnya ditunjuk pada tabel dibawah ini: 
Tabel 4.2 Lembar refleksi Siklus I tingkat ketuntasan individu dengan penerapan metode cooperative learning.

\begin{tabular}{|c|c|c|c|c|c|c|}
\hline \multirow{3}{*}{ No } & \multirow{3}{*}{ Nama Mahasiswa } & \multicolumn{2}{|c|}{ NA $=\underline{\text { SHT }} \times$ NI } & \multirow{3}{*}{ Predikat } & \multirow{3}{*}{ Tuntas ( $T$ ) } & \multirow{3}{*}{ Tidak Tuntas ( TT ) } \\
\hline & & & SMI & & & \\
\hline & & Skor & Nilai (\%) & & & \\
\hline 1 & BAYU WIDIANTO & 25 & 69,44 & $\mathrm{C}$ & & $\sqrt{ }$ \\
\hline 2 & RIMUDI & 33 & 91,66 & $\mathbf{A}$ & $\sqrt{ }$ & \\
\hline 3 & FRIDATA YODHO & 28 & 77,77 & B & $\sqrt{ }$ & \\
\hline 4 & DANAG YOGI & 29 & 80,55 & B & $\sqrt{ }$ & \\
\hline 5 & SANDI ARIF H. & 34 & 94,44 & $\mathbf{A}$ & $\sqrt{ }$ & \\
\hline 6 & ADITYA WAHYU P & 23 & 63,88 & $\mathrm{C}$ & & $\sqrt{ }$ \\
\hline 7 & INDRA BAGUS W. & 29 & 69,44 & B & $\sqrt{ }$ & \\
\hline 8 & DODO ERWIN D. & 24 & 66,66 & $\mathrm{C}$ & & $\sqrt{ }$ \\
\hline 9 & UBAIDILLAH & 27 & 75 & B & $\sqrt{ }$ & \\
\hline 10 & NELSON LANDU T & 30 & 83,33 & B & $\sqrt{ }$ & \\
\hline 11 & M. SUPRIYADI & 34 & 94,44 & A & $\sqrt{ }$ & \\
\hline 12 & FACHRI B. & 32 & 88,88 & A & $\sqrt{ }$ & \\
\hline 13 & MOH. NUR S. & 23 & 63,88 & $\mathrm{C}$ & & $\sqrt{ }$ \\
\hline 14 & SATRIO WAHYU U & 25 & 69,44 & $\mathrm{C}$ & & $\sqrt{ }$ \\
\hline 15 & SUBHAN W. & 32 & 88,88 & A & $\sqrt{ }$ & \\
\hline 16 & FAHMI Q & 33 & 91,66 & $\mathbf{A}$ & $\sqrt{ }$ & \\
\hline 17 & YOHANES A. & 26 & 72,22 & $\mathrm{C}$ & & $\sqrt{ }$ \\
\hline 18 & WILDAN FAHMI H & 30 & 83,33 & B & $\sqrt{ }$ & \\
\hline 19 & ARIF RAHMAN K. & 33 & 91,66 & $\mathbf{A}$ & $\sqrt{ }$ & \\
\hline 20 & DELIANUS S. & 28 & 77,77 & B & $\sqrt{ }$ & \\
\hline 21 & MARTINUS PA. & 34 & 94,44 & A & $\sqrt{ }$ & \\
\hline 22 & HENDRA & 30 & 83,33 & B & $\sqrt{ }$ & \\
\hline 23 & JURIANDRA S. & 20 & 55,55 & $\mathrm{D}$ & & $\sqrt{ }$ \\
\hline 24 & SUSETIONO MA. & 30 & 83,33 & B & $\sqrt{ }$ & \\
\hline 25 & WAWAN A. & 26 & 72,22 & $\mathrm{C}$ & & $\sqrt{ }$ \\
\hline 26 & IQBAL W. & 24 & 66,66 & $\mathrm{C}$ & & $\sqrt{ }$ \\
\hline 27 & JONI ANGGARA & 30 & 83,33 & B & $\sqrt{ }$ & \\
\hline 28 & MOH. ABIDIN & 25 & 69,44 & $\mathrm{C}$ & & $\sqrt{ }$ \\
\hline 29 & RIZKI NURCAHYO & 29 & 80,55 & B & $\sqrt{ }$ & \\
\hline \multirow[t]{3}{*}{30} & ONGKY DANGE U. & 26 & 72,22 & C & & $\sqrt{ }$ \\
\hline & Jumlah & 825 & 2355,4 & & 19 & 11 \\
\hline & Rata-rata & 28,4 & 78,51 & B (Baik) & $=63,33 \%$ & $=36,67$ \\
\hline
\end{tabular}

Berdasarkan data hasil belajar dan tes dalam penerapan metode cooperative learning untuk meningkatkan hasil belajar pada siklus I, dapat dikelompokkan kategori hasil belajar mahasiswa pada tabel di bawah ini. Untuk keterangan lebih lanjut dapat dilihat pada lampiran. 
12 | Sulikan, Penerapan Metode Cooperative Learning ...

Tabel 4. 3 Presentase Ketuntasan Hasil Belajar Renang Gaya Bebas pada Siklus I dengan penerapan metode cooperative learning.

\begin{tabular}{llllll}
\hline No. & Kategori & $\begin{array}{c}\text { Jumlah } \\
\text { mahasiswa }\end{array}$ & $\begin{array}{c}\text { Presentase } \\
\mathrm{KB}=\frac{\mathrm{F}}{\mathrm{N}} \times 100 \%\end{array}$ & $\begin{array}{c}\text { Akumulasi } \\
\text { Ketuntasan }\end{array}$ & \multicolumn{1}{c}{ T/TT } \\
\hline 1. & SANGAT BAIK & 8 & $26,66 \%$ & $26,66 \%$ & 19 Mahasiswa tuntas \\
2. & BAIK & 11 & $36,66 \%$ & $36,67 \%$ & 11 mahasiswa tidak tuntas \\
3. & CUKUP & 10 & $33,33 \%$ & - & \\
4. & KURANG & 1 & $3,33 \%$ & & \\
\hline \multicolumn{2}{l}{ TOTAL } & 30 & $100 \%$ & $63,33 \%$ & \\
\hline
\end{tabular}

Keterangan :

$\mathrm{KB}=$ Ketuntasan Belajar

$\mathrm{F}=$ Frekuensi mahasiswa tuntas / tidak tuntas

$\mathrm{N}=$ Jumlah seluruh mahasiswa

Sesuai dengan data Penelitian Tindakan Kelassiklus I, makaketuntasanbelajarmahasiswa secara klasikal untuk materi renang Gaya Bebas sebesar $63,34 \%$, dengan penghitungan, yaitu:

\section{KB $\times 100 \%$}

$$
\mathrm{KB}=(19: 30) \times 100 \%=63,33 \%
$$

Secara umum dapat disimpulkan bahwa Penelitian Tindakan Kelas siklus I pada Mahasiswa Pendidikan Jasmani Kesehatan Dan Rekreasi IKIP Budi Utomo Malang, untuk penguasaan materi secara klasikal, yaitu kemampuan Renang Gaya Bebas "Cukup", karena hanya mampu mencapai 63,33\%, sedangkan kriteria ketuntasan ( KKM ) secara klasikal adalah $70 \%$. Oleh karena itu, peneliti menerapkan pembelajaran lanjutan, yaitu menerapkan metode cooperative learning pada siklus II.

\section{Penelitian Tindakan Kelas siklus II \\ a. Perencanaan}

Perencanaan di siklus ke dua diawali dengan penentuan perencanaan di siklus ke II diawali dengan penentuan waktu tindakan kelas yaitu hari Senin, 1 Juni dan 8 Juni 2015. Setelah melakukan tindakan selanjutnya penentuan materi pembelajaran baik permaianan (games) dan materi yang akan dilaksanakan, setelah itu penilaian atau pencatatan hasil Renang gaya bebas, selanjutnya adalah tanggapan mahasiswa tentang pembelajaran renang Gaya Bebas melalui penerapan metode cooperative learning.

\section{b. Pengamatan}

Suasana kelas sangat kondusif, tertib dan mahasiswa terlihat sangat aktif dan antusias, sehingga banyak mahasiswa yang mampu melakukan gerakan renang Gaya Bebas dengan baik dan benar walau ada beberapa mahasiswa yang belum mampu melaksanakan dengan baik dan benar.

Proses pengambilan nilai atau pencatatan hasil, dosen memanggil satu persatu sesuai urut absen dari nomor absen yang terkecil, tiap mahasiswa berkesempatan 3 kali kesempatan tes, mahasiswa yang susdah melakukan atau yang menunggu giliran kebanyakan mengamati teman yang melakukan tes dan memberikan dorongan semangat dengan cara bertepuk tangan.

Pembelajaran renang Gaya Bebas dengan penerapan metode cooperative learning yang sudah dilaksanakan, dilihat dari sudut pandang mahasiswa, mahasiswa sangat aktif dan antusias dalam memngikuti pembelajaran. Dalam proses pembelajaran mahasiswa secara tidak langsung belajar teknik dasar Renang Gaya Bebas yang benar, dengan demikian memudahkan dosen dalam melaksanakan pembelajaran.

\section{c. Refleksi}

Setelah dilakukan pengamatan dan evaluasi maka langkah selanjutnya adalah refleksi dari tindakan yang telah dilakukan. Dari hasil penilaian atau pengukuran tersebut dapat dikatakan bahwa tindakan yang dilakukan sudah tepat dan tidak perlu lagi dilakukan tindakan. Hasil refleksi penelitian tandakan kelas, ditunjuk pada tabel dibawah ini: 
Tabel 4. 4 Lembar Refleksi Siklus II tingkat ketuntasan individu dengan penerapan metode cooperative learning.

\begin{tabular}{|c|c|c|c|c|c|c|}
\hline \multirow[t]{2}{*}{ No } & \multirow[t]{2}{*}{ Nama Mahasiswa } & \multicolumn{2}{|c|}{$\mathrm{NA}=\frac{\text { SHT }}{S M I} X \mathrm{NI}$} & \multirow[t]{2}{*}{ Predikat } & \multirow[t]{2}{*}{ ( T ) Tuntas } & \multirow[t]{2}{*}{ ( TT ) Tidak Tuntas } \\
\hline & & Skor & Nilai (\%) & & & \\
\hline 1 & BAYU WIDIANTO & 29 & 80,55 & B & $\sqrt{ }$ & \\
\hline 2 & RIMUDI & 35 & 97,22 & $\mathbf{A}$ & $\sqrt{ }$ & \\
\hline 3 & FRIDATA YODHO & 35 & 97,22 & A & $\sqrt{ }$ & \\
\hline 4 & DANAG YOGI & 31 & 86,11 & B & $\sqrt{ }$ & \\
\hline 5 & SANDI ARIF H. & 36 & 100 & A & $\sqrt{ }$ & \\
\hline 6 & ADITYA WAHYU P & 26 & 72,22 & $\mathrm{C}$ & & $\sqrt{ }$ \\
\hline 7 & INDRA BAGUS W. & 31 & 86,11 & B & $\sqrt{ }$ & \\
\hline 8 & DODO ERWIN D. & 31 & 86,11 & B & $\sqrt{ }$ & \\
\hline 9 & UBAIDILLAH & 36 & 100 & $\mathbf{A}$ & $\sqrt{ }$ & \\
\hline 10 & NELSON LANDU T & 35 & 97,22 & $\mathbf{A}$ & $\sqrt{ }$ & \\
\hline 11 & M. SUPRIYADI & 36 & 100 & A & $\sqrt{ }$ & \\
\hline 12 & FACHRI BA. & 35 & 97,22 & A & $\sqrt{ }$ & \\
\hline 13 & MOH. NUR S. & 26 & 72,22 & $\mathrm{C}$ & & $\sqrt{ }$ \\
\hline 14 & SATRIO WAHYU U & 31 & 86,11 & B & $\sqrt{ }$ & \\
\hline 15 & SUBHAN W. & 36 & 100 & A & $\sqrt{ }$ & \\
\hline 16 & FAHMI Q & 35 & 97,22 & A & $\sqrt{ }$ & \\
\hline 17 & YOHANES A. & 31 & 86,11 & B & $\sqrt{ }$ & \\
\hline 18 & WILDAN FAHMI H & 31 & 86,11 & B & $\sqrt{ }$ & \\
\hline 19 & ARIF RAHMAN K. & 36 & 100 & A & $\sqrt{ }$ & \\
\hline 20 & DELIANUS . & 31 & 86,11 & B & $\sqrt{ }$ & \\
\hline 21 & MARTINUS PA. & 35 & 97,22 & $\mathbf{A}$ & $\sqrt{ }$ & \\
\hline 22 & HENDRA & 31 & 86,11 & B & $\sqrt{ }$ & \\
\hline 23 & JURIANDRA S. & 31 & 86,11 & B & $\sqrt{ }$ & \\
\hline 24 & SUSETIONO MA. & 30 & 83,33 & B & $\sqrt{ }$ & \\
\hline 25 & WAWAN A. & 30 & 83,33 & B & $\sqrt{ }$ & \\
\hline 26 & IQBAL W. & 31 & 86,11 & B & $\sqrt{ }$ & \\
\hline 27 & JONI ANGGARA & 36 & 100 & A & $\sqrt{ }$ & \\
\hline 28 & MOH. ABIDIN & 30 & 83,33 & B & $\sqrt{ }$ & \\
\hline 29 & RIZKI NURCAHYO & 31 & 86,11 & B & $\sqrt{ }$ & \\
\hline \multirow[t]{3}{*}{30} & ONGKY DANGE U. & 31 & 86,11 & B & $\sqrt{ }$ & \\
\hline & Jumlah $=$ & 969 & 2691,62 & & 28 & 2 \\
\hline & Rata-rata & 32,3 & 89,72 & A ( SB ) & $93,33 \%$ & $6,67 \%$ \\
\hline
\end{tabular}

Berdasarkan data hasil belajar dan tes dalam penerpan metode cooperative learning untuk meningkatkan hasil belajar pada siklus II, dapat dikelompokkan kategori hasil belajar mahasiswa pada tabel di bawah ini. Untuk keterangan lebih lanjut, dapat dilihat pada lampiran. 
14 | Sulikan, Penerapan Metode Cooperative Learning ...

Tabel 4. 5 Presentase Ketuntasan Hasil Belajar Renang Gaya Bebas dengan penerapan metode cooperative learning Pada Siklus II

\begin{tabular}{llllll}
\hline No. & Kategori & \multicolumn{1}{c}{$\begin{array}{c}\text { Jumlah } \\
\text { mahasiswa }\end{array}$} & $\begin{array}{c}\text { Presentase } \\
\mathrm{KB}=\frac{\mathrm{F}}{\mathrm{N}} \times 100 \%\end{array}$ & $\begin{array}{c}\text { Akumulasi } \\
\text { Ketuntasan }\end{array}$ & \multicolumn{1}{c}{ T/TT } \\
\hline 1. & SANGAT BAIK & 12 & $40 \%$ & $40 \%$ & 28 Mahasiswa tuntas \\
2. & BAIK & 16 & $53,33 \%$ & $53,33 \%$ & 2 mahasiswa tidak tuntas \\
3. & CUKUP & 2 & $6,67 \%$ & - & \\
4. & KURANG & - & - & - & $93,33 \%$ \\
\multicolumn{2}{l}{ TOTAL } & 30 & $100 \%$ & &
\end{tabular}

\section{Keterangan :}

$\mathrm{KB}=$ Ketuntasan Belajar

$\mathrm{F}=$ Frekuensi mahasiswa tuntas / tidak tuntas

$\mathrm{N}=$ Jumlah seluruh mahasiswa

SesuaidengandataPenelitianTindakanKelas siklus II,maka ketuntasan belajar mahasiswa secara klasikal untuk materi Renang Gaya Bebas sebesar 93,33\%, dengan penghitungan, yaitu:

\section{KB $\times 100 \%$}

$$
\mathrm{KB}=(28: 30) \times 100 \%=93,33 \%
$$

Dengan demikian, secara umum dapat disimpulkan bahwa Penelitian Tindakan Kelas siklus II pada Mahasiswa Pendidikan Jasmani Kesehatan Dan Rekreasi IKIP Budi Utomo Malang, untuk penguasaan materi secara klasikal, dengan Penerapan Metode cooperative learning untuk Meningkatkan Hasil Belajar Renang Gaya Bebas, telah berhasil karena mampu mencapai 93,33\%. Hal ini sesuai dengan kriteria ketuntasan secara klasikal, yaitu $70 \%$. Dengan telah tercapainya hasil tersebut, maka penelitian ini dihentikan. Hal ini dikarenakan batas minimal penguasaan materi secara klasikal oleh Mahasiswa Pendidikan Jasmani Kesehatan Dan Rekreasi IKIP Budi Utomo Malang, yaitu $70 \%$, telah tercapai.

\section{Kesimpulan Hasil Penelitian Tindakan Kelas siklus I dan siklus II}

Berdasarkan hasil analisis data pada siklus I pada Mahasiswa Pendidikan Jasmani Kesehatan Dan Rekreasi IKIP Budi Utomo Malang, untuk penguasaan materi kemampuan renang Gaya Bebas secara klasikal, adalah sebesar 63,33\%, dengan tingkat kelulusan termasuk kriteria 'Cukup', karena belum mampu mencapai target minimum kelulusan secara klasikal, yaitu 70\%, sehingga peneliti melanjutkan penelitian menuju siklus II.

Berdasarkan hasil analisis data siklus II pada Mahasiswa Pendidikan Jasmani Kesehatan Dan Rekreasi IKIP Budi Utomo Malang, untuk penguasaan materi Penerapan Metode Cooperative Learning untuk Meningkatkan Hasil Belajar Renang Gaya Bebas secara klasikal, adalah 93,33\%, dengan tingkat kelulusan termasuk kriteria 'Sangat Baik', karena telah mampu mencapai target minimum kelulusan secara klasikal, yaitu $70 \%$.

Melihat dari hasil penelitian di atas, maka dapat disimpulkan bahwa hasil belajar mahasiswa meningkat dari 63,34\% dengan kriteria kelulusan 'Cukup' menjadi 93,33 \% dengan kriteria kelulusan 'Sangat Baik', pada Penerapan Metode Cooperative Learning untuk Meningkatkan Hasil Belajar Renang Gaya Bebas Mahasiswa Pendidikan Jasmani Kesehatan Dan Rekreasi IKIP Budi Utomo Malang Angkatan 2014.

\section{KESIMPULAN DAN SARAN}

Sesuai dengan hasil penelitian, analisis data, dan pembahasan, maka peneliti memberikan kesimpulan bahwa hasil belajar mahasiswa meningkat dari 16,67\% pada Tes Awal (Pra Siklus) menjadi 63,33\% dengan kriteria kelulusan 'Cukup' pada Siklus I menjadi 93,33\% dengan kriteria kelulusan 'Sangat Baik' pada Siklus II.

Dengan demikian Penerapan Metode Cooperative Learning dapat Meningkatkan Hasil Belajar Renang Gaya Bebas pada Mahasiswa Pendidikan Jasmani Kesehatan 
Dan Rekreasi IKIP Budi Utomo Malang Angkatan 2014. Hal ini dimungkinkan karena dalam proses pembelajarannya menyenangkan dan peningkatkan penguasaan keterampilan mahasiswa terhadap teknik dasar renang Gaya Bebas.

Berdasarkan hasil penelitian ini, maka saran-saran yang dapat penulis kemukakan, antara lain:

\section{Bagi mahasiswa}

Diharapkan hasil penelitian ini dapat dijadikan sebagai informasi bagi mahasiswa guna meningkatkan hasil belajar renang Gaya Bebas melalui penerapan metode cooperative learning,karena melalui metode pembelajaran seperti ini dapat meningkatkan minat dan gairah untuk mempelajari teknik dasar renang.

\section{Bagi Para Dosen Penjaskes}

Diharapkan agar dapat menggunakan hasil penelitian ini sebagai pedoman maupun bekal untuk melatih para mahasiswa, jika ingin meningkatkan hasil belajar renang Gaya Bebas.

\section{Bagi para peneliti}

a. Hendaknya hasil penelitian ini dapat di jadikan pedoman atau sebagai pembanding guna mendapatkan hasil penelitian serupa yang lebih baik lagi.

b. Diharapkan penggunaan subyek penelitian yang lebih bervariasi dan lebih luas guna pengembangan hasil penelitian selanjutnya.

\section{DAFTAR PUSTAKA}

Arikunto,S, dkk. 2008, Penelitian Tindakan Kelas, dalam P3G, 2013, Makalah Penelitian Tindakan Kelas, IKIP Budi Utomo Malang.

Departemen Pendidikan Nasional, 2006. Model Kurikulum Tingkat Satuan Pendidikan, Jakarta.

Hijrah, S,.2012. Model Pembelajaran Kooperatif (Cooperative Learning). (online), (yaitu http:/ / syaifulhijrah.blogspot.com/ posted on 10:51 AM /2012/11/page/20).

Kementerian Pendidikan dan Kebudayaan. 2014. Pendidikan Jasmani, Olahraga, dan Kesehatan. Jakarta: Politeknik Negeri Media Kreatif.

Mardiana,A..2010. Materi Pokok pendidikan jasmani dan olahraga.Jakarta: Universitas Terbuka.

Muhajir. 2014. Pendidikan Jasmani Olahraga dan Kesehatan untuk SMA/MA Kelas X. Bandung: Erlangga.

Susetyo,B. 2005. Teknik Penelitian Tindakan Kelas untuk Guru PLB. Jakarta: Pendidikan Luas Biasa Departemen Pendidikan Nasional Republik Indonesia

Universitas Negeri Malang. 2007. Pedoman Penulisan Karya Ilmiah. Malang: Universita Negeri Malang Press.

Wahyuni,S. 2010. Pendidikan Jasmani, Olahraga,dan Kesehatan 1. Jakarta:Pusat Perbukuan, Kementerian Pendidikan Nasional.

Wiriatmadja, R. 2007. Metode Penelitian Tindakan Kelas untuk Meningkatkan Kinerja Guru dan Dosen. Bandung: Remaja Rosda Karya. 
16 | Sulikan, Penerapan Metode Cooperative Learning ... 